\title{
MINAT GENERASI MILLENIAL UNTUK MEMBELI VIRTUAL TOUR
}

\author{
M. Tanggap Sasmita \\ Email: tanggap1511@gmail.com \\ Politeknik Pariwisata Lombok
}

\begin{abstract}
The Covid-19 pandemic has an impact on the world of tourism due to restrictions on travel activities, resulting in the emergence of alternative virtual travel activities. Virtual tour activities are actually not new, but more popular during the covid-19 pandemic. As a new activity for travel industry needs, it's need to do basic research for the for marketing activities in the future to be monetize by looking at the quality of service, level of satisfaction, and interest of millennial generation to buy this service. By using cross-tabulation method and descriptive analysis techniques the findings of this study that the quality of good service is in line with the level of satisfaction and interest of millennials to buy virtual tour activities in the future with a range of $\mathrm{Rp} .10 .000-\mathrm{Rp} .50 .000$ in each activity. More research is needed to find out the right strategy in marketing virtual tour activities.
\end{abstract}

Abstrak: Pandemi Covid-19 membawa dampak pada dunia pariwisata akibat adanya pembatasan aktifitas perjalanan, sehingga munculah sebuah alternatif kegiatan berwisata secara virtual. Kegiatan virtual tour sebenarnya bukanlah hal yang baru, namun kian popular di masa pandemi covid-19. Sebagai kegiatan yang baru bagi dunia industri perjalanan maka perlu dilakukan penelitian dasar dari kegiatan pemasaran virtual tour sehingga kedepanya kegiatan virtual tour dapat menjadi sebuah kegiatan bisnis pariwisata yang dapat dimonetasi dengan melihat kualitas pelayanan, tingkat kepuasan, dan minat generasi meillenial untuk membeli layanan ini. Dengan menggunakan metode tabulasi silang dan teknik analisa deskriptif temuan dari penelitian ini menunjukkan bahwa kualitas pelayanan yang baik sejalan dengan tingkat kepuasan serta minat generasi millenial untuk membeli kegiatan virtual tour di masa yang akan datang dengan kisaran haraga Rp.10.000- Rp.50.000 dalam setiap kegiatanya. Penelitian lebih lanjut diperlukan untuk mengetahui strategi yang tepat dalam memasarkan kegiatan virtual tour.

Keywords: interest, millennial, virtual tours.

\section{PENDAHULUAN}

Pandemi covid-19 mengakibatkan banyak perubahan dalam tatanan kehidupan masyarakat termasuk di industri pariwisata. Pergerakan industri pariwisata yang begitu dinamis harus direm sejenak karena adanya larangan untuk melakukan perjalanan dan menghindari kerumanan. Salah satu alternatif yang bisa dilakukan dan berkembang di saat pandemi adalah melakukan kegiatan virtual tour. Menurut sebuah artikel dalam portal berita berikut Banyak Peminat, Bersukaria Walk Bakal Lanjutkan Virtual Walking Tour (inibaru.id) dikatakan bahwa animo masyarakat untuk mengikuti virtual tour cukup tinggi, hal ini dianggap mampu mengobati kerinduan orang orang-orang untuk melakukan perjalanan.
Dalam sebuah artikel yang berjudul "Tren Virtual Tour di Masa Pandemi Covid-19" ditulis bahwa dengan virtual tour bisa mengajak wisatawan seolah-olah melakukan perjalanan wisata langsung ke destinasi yang dituju. Suatu virtual tour dapat dikatakan sukses jika didukung oleh koneksi internet yang baik, tim teknis, serta pemahamanan pemandu wisata sehingga mampu menciptakan suasana perjalanan. Hal senada di dukung oleh pendapat (Prasetya, 2011) yang menuliskan bahwa komponen utama dan kunci keberhasilan virtual tour adalah gambar yang dilengkapai dengan multimedia lain seperti efek suara, musik, narasi, dan teks yang baik.

Dalam sebuah artikel yang ditulis oleh (Namrata Bakre, 2017) menyatakan bahwa 
virtual tour adalah bagian dari revolusi perjalanan digital. Konsep dari virtual tour datang dari payung ruang virtual atau cyberspace, ada jalan untuk orang menjelajah dan mendapatkan pengalaman melalui internet dari sebuah tempat yang sebenarnya eksis secara nyata. Dengan hadirnya pandemi covid19 memaksa industri pariwisata untuk mempercepat langkahnya dalam penggunaan teknologi dan generasi millenial adalah generasi yang dekat dengan penggunaan teknologi.

Dari hasil observasi saat ini penyedia layanan virtual tour berasal dari agen perjalanan, komunitas, ataupun pribadi dan dilaksanakan secara cuma-cuma ataupun berbayar. Adapun teknologi yang digunakan bermacam-macam, seperti kamera foto dan video 360 dan aplikasi zoom, selain itu ada pula penyedia yang menggunakan aplikasi google street map dan youtube sebagai media penyebaranya.

Pada penelitian-penelitan sebelumnya mengenai virtual tour dan kegiatan pariwisata telah dilakukan oleh beberapa penulis seperti yang dilakukan oleh Cho, Y.Y (2002) yang mencoba menemukenali konsep dari virtual tour dengan web based virtual tour dan menguji dampak virtual tour dalam pemasaran pariwisata, Penelitian lain dilakukan oleh Wulur H.W (2015) yang megembangkan sebuah aplikasi interaktif yang dapat menampilan informasi secara visual dari suatu tempat wisata alam di Sulawesi Utara. Penelitian Pladitama R. (2015) yang menggunakan layanan virtual tour sebagai media pengenalan situs Trowulan kepada masyarakat umum dengan harapan dapat menumbuhkan minat masyarakat untuk berkunjung. Dari penelitan-penelitian tersebut diketahui bahwa virtual tour sudah dikembangkan sebelum masa pandemi dan kembali populer saat ini. Jika diperhatikan lebih lanjut terdapat kesamaan bahwa virtual tour digunakan untuk kegiatan pemasaran atau alat pemasaran untuk menarik sesoarang datang berkunjung. Sedikit berbeda dengan dengan beberapa penelitian di atas penelitian ini melihat virtual tour sebuah layanan utuh yang dilakukan bukan untuk pemasaran destinasi namun menggantikan kegiatan berwisata yang sesungguhnya, selain itu penelitian kali ini untuk mengetahui kualitas layanan dari penyedia, tingkat kepuasan peserta, dan minat generasi millenial untuk mengikuti dan membeli layanan virtual tour di masa pandemi covid-19.

Menurut Mark Plus Centre for Tourism and Hospitality (2014) menyatakan bahwa wisatawan millennial memiliki karakter personal dan kedekatanya pada teknologi, ukuran dan kekuatan mempengaruhinya cukup besar, oleh karenanya membutuhkan strategi pemasaran yang unik. Selain itu virtual tour adalah fenomena yang baru di dunia pariwisata di tengah pandemi Covid -19 saat ini, sehingga penting untuk dibahas dan diteliti lebih lanjut untuk melihat prospeknya kedepan.

\section{METODELOGI}

Menurut Wibisono dalam Akdon, dan Riduan (2013) karena jumlah dari millenial di Indonesia tidak diketahui jumlahnya dan cukup banyak, dengan tingkat kepercayaan 95\% bahwa sample random berukuran 97 akan memberikan selisih estimasi dengan kurang dari 0,05. Dalam penelitian ini disebarkan sebanyak 150 kuesioner dan kembali sebanyak 147 kuesioner, sebelum disebar luaskan kuesioner diujicobakan terlebih dahulu dengan uji validitas dan reabilitas terhadap 30 kuesioner pertama.

Data dikumpulkan dengan kuesioner yang disebar secara daring kepada para generasi millennial, Menurut (Deal, Altman, Rogelberg (2010) mendefinisikan generasi millennial adalan mereka yang lahir di tahun 1980-an dan memasuki pasar kerja di tahun 2000-an. Mereka adalah generasi awal yang berpendidikan tinggi, dan berkompetensi tinggi dalam penggunakan teknologi informasi dan komunikasi, dan dekat dengan dunai media sosial. Sesuai dengan definisi di atas maka yang menjadi responden dalam penelitian adalah generasi millennial yang lahir dari tahun 1980an hingga awal 2001-an. Adapun pertanyaanpertanyaan utama dalam kuesioner yang disebarkan diantaranya, kepuasan generasi millennial terhadap fitur yang dari virtual tour itu sendiri seperti interaksi, multimedia, registrasi, pemandu, promosi dan kenyataan, kemampuan menyelesaikan masalah, selain itu adalah meminta tanggapan responden terhadap keinginan untuk mengikuti virtual tour kembali, kesediaan untuk membayar, dan rentang harga yang sanggup mereka bayarkan 
untuk mengikuti satu kali virtual tour. Kemudian dari hasil data yang diperoleh dari penyebaran kuesioner tersebut diolah dengan analisis tabulasi silang antara karakteristik dengan tabulasi frekeunsi hasil kuesioner, kemudian di analisis secara deksriptif dengan membandingkan dengan konsep, teori, hasil observasi dan wawancara Salah satu ciri-ciri dari penggunaan tabulasi silang adalah data input yang digunakan yaitu data nominal atau ordinal sehingga akan menghasilkan output yang dapat dijelaskan secara deskriptis (Sarwono, 2009).

\section{HASIL DAN PEMBAHASAN}

Pada masa pandemi covid-19 ini layanan yang sifatnya virtual atau online menjadi sangat penting dan didukung dengan perkembangan perdagangan barang dan jasaa saat ini yang sudah mengarah ke online dan virtual. Menurut (Sousa \& Viss, 2009) mendefinisikan layanan online sebagai "the delivery as service using new media such as the web". Pengertian tersebut berarti penyerahan barang atau jasa dengan menggunakan media yang baru yaitu website. Keberadaan bukti dari kualitas layanan atas penyerahan barang atau jasa melalui website merupakan kesuksesan strategi yang sangat penting dibandingkan dengan harga murah dan keberadaan web. Hal ini sejalan dengan munculnya virtual tour sebagai layanan alternatif bagi masyarakat khusunya generasi millenial yang ingin berwisata namun harus terhalang karena kondisi pandemi Covid-19 saat ini yang biasanya dilakukan dengan bepergian secara langsung dengan layanan ini peserta hanya diam di rumah sudah mampu memiliki pengalaman berwisata secara online. Hana (2019) dalam hasil penelitianya yang berjudul "Minat Online Generasi Millenial: Pengaruh Kepercayaan dan Kualitas Layanan" menemukan bahwa generasi millenial akan berminat melakukan pembelian online berdasarkan tingkat kepercayaan dan tingkat kualitas layanan yang ditawarkan.

Virtual tour yang menjadi objek penelitian ini adalah virtual tour yang objek kunjunganya adalah tempat wisata. Dalam penelitian ini ditunjukkan bahwa kualitas layanan dari penyedia layanan virtual tour berada di level baik dan baik sekali yang menumbuhkan kemungkinan generasi millenial membeli layanan ini sesperti yang ditemukan dalam Tabel 1.

Tabel 1. Tabulasi Silang Kareteristik dengan Kualitas Pelayanan

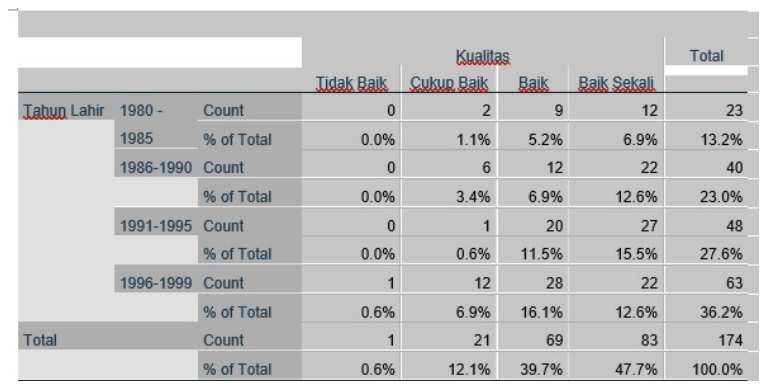

Sumber : Hasil Penelitian, 2020.

Pelayanan yang diberikan memberikan dampak yang sangat positif bagi konsumen dan merupakan suatu keunggulan yang dimiliki oleh perorangan ataupun usaha dibidang jasa dan dagang (Tjiptono \& Chandra, 2005). Penilaiain negatif dan positif dari konsumen yang diberikan oleh suatu instansi atau organisasi dan berdampak pada suatu kepuasan (Asubonteng dalam Hidayatullah, dkk., 2020). Dari konsep di atas dapat ditarik kesimpulan bahwa kualitas pelayanan yang baik akan membawa pengaruh pada tingkat kepuasan dari konsumen atau pengguna jasa. Hal ini juga nampak dari hasil penelitian ini, di mana nilai kualitas pelayanan dari sebagian besar responden menjawab baik dan sangat baik yang berujung pada nilai tingkat kepuasan yang diberikan oleh responden juga pada nilai puas dan puas sekali. Namun perlu penelitian lebih lanjut apakah kualitas pelayanan yang diberikan berpengaruh siginfikan terhadap tingkat kepuasan, ataukah faktor lainnya yang menjadi dasar tingkat kepuasan generasi millenial dalam mengikuti virtual tour. Seperti halnya dalam penelitian (Hidaytaullah, dkk., 2020) yang menyatakan bahwa kualitas pelayanan tidak berpengaruh terhadap kepuasan, namun ada faktor lain yang menyebabkan generasi millenial untuk mengunjungi atraksi wisata. Hubungan antara karakteristik responden dengan kepuasan dapat dilihat dalam Tabel 2. 
Tabel 2.Tabulasi silang Karakteristik dengan Tingkat Kepuasan

\begin{tabular}{|c|c|c|c|c|c|c|c|}
\hline & & & & Keluas & & & Total \\
\hline & & & Tidak Puas & $\begin{array}{l}\text { Cubur } \\
\text { Puas. }\end{array}$ & Ruas. & $\begin{array}{l}\text { Puas } \\
\text { Sekali. }\end{array}$ & \\
\hline Jahun & $1980-1985$ & Count & 0 & 1 & 9 & 13 & 6 \\
\hline Lahir & & $\%$ of Total & $0.0 \%$ & $0.6 \%$ & $5.2 \%$ & $7.5 \%$ & $13.2 \%$ \\
\hline & 1986-1990 & Count & 0 & 5 & 11 & 24 & 40 \\
\hline & & $\%$ of Total & $0.0 \%$ & $2.9 \%$ & $6.3 \%$ & $13.8 \%$ & $23.0 \%$ \\
\hline & 1991-1995 & Count & 0 & 1 & 13 & 34 & 48 \\
\hline & & $\%$ of Total & $0.0 \%$ & $0.6 \%$ & $7.5 \%$ & $19.5 \%$ & $27.6 \%$ \\
\hline & 1996-1999 & Count & 1 & 14 & 21 & 27 & 63 \\
\hline & & $\%$ of Total & $0.6 \%$ & $8.0 \%$ & $12.1 \%$ & $15.5 \%$ & $36.2 \%$ \\
\hline Total & & Count & 1 & 21 & 54 & 98 & 174 \\
\hline & & $\%$ of Total & $0.6 \%$ & $12.1 \%$ & $31.0 \%$ & $56.3 \%$ & $100.0 \%$ \\
\hline
\end{tabular}

Sumber: Hasil Penelitian, 2020.

Setelah melihat reaksi generasi millenial terhadap kualitas pelayanan dan kepuasanya yang mengarah kepada minat generasi millenial untuk mengikuti dan membeli virtual tour. Anwar (2020) dalam penelitianya mengatakan bahwa dalam beberapa literarur menyatakan bahwa minat pembelian kembali adalah proses pengulangan pembelian barang atau jasa dari suatu gerai dan alasanya adalah pengalaman setelah bebelanja. Didalam literatur pemasaran lain dikatakan bahwa beberapa studi menyatakan adanya hubungan adanya kualitas layanan dan pembelian kembali atau dengan kata lain bahwa kualitas layanan memili dampak positif terhadap minat pembelian kembali atau dapat dikatakan dengan meningkatkan kepuasan maka minat pembelian kembali akan semakin meningkat dan berlaku juga dalam layanan yang sifatnya online atau virtual. Hal ini sejalan dengan penelitian ini dimana kualitas pelayanan yang baik berdampak pada tingkat kepuasan yang baik dan minat untuk mengikuti kembali layanan virtual tour di kemudian hari, sesuai dengan data hasil penelitian yang telah diolah dalam Tabel 3.

Tabel 3. Minat Generasi Millenial Membeli Layanan Virtual Tour

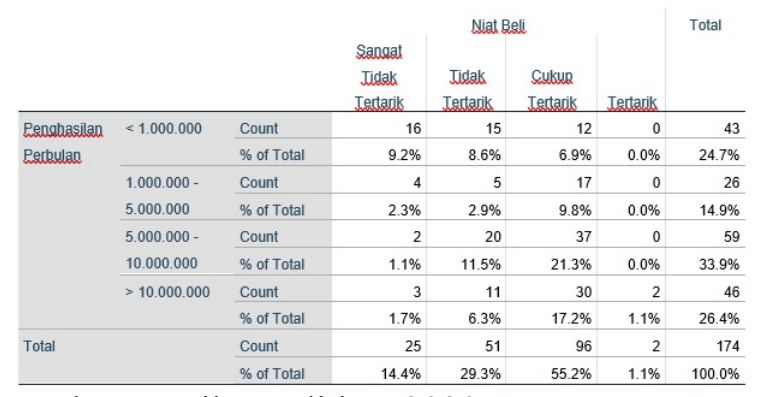

Sumber: Hasil Penelitian, 2020.
Saat ini banyak layanan virtual tour yang sifatnya gratis atau sukarela, jika diadakan lagi virtual tour kembali di masa yang akan datang 90 persen dari responden berminat untuk mengikutinya kembali, apalagi jika gratis dan sukarela, namun seandainya pun berbayar dalam penelitian ini juga meneliti nilai yang sanggup dibayarkan oleh generasi millenial jika akan mengikuti kegiatan virtual tour di kemudian hari dan didapatkan jawaban sebagian besar responden sanggup membayar di kisaran Rp. 10.000-Rp. 50.000 untuk satu kali kegiatan virtual tour. Nilai tersebut merupakan nilai yang cukup pantas bagi generasi millenial. Menurut El Said dan Aziz (2012) menyatakan kedepanya virtual tour dapat dijadikan media promosi sebuah destinasi wisata dan sebuah alternatif produk wisata di masa pandemi, pernyataan ini mendukung pendapat Huang dan Backman (2010) yang dalam hasil penelitianya dinyatakan bahwa 42 responden yang telah mengalami pengalaman virtual berminat untuk melakukan perjalanan faktualnya di kemudian hari.

\section{SIMPULAN DAN SARAN Simpulan}

Dari penelitian tersebut, dapat ditarik kesimpulan bahwa kualitas pelayanan memberikan dampak pada tingkat kepuasan dan minat generasi millenial untuk membeli layanan virtual tour. Kualitas layanan virtual tour yang baik membawa nilai puas dan tingkat minat geneasi millenial tertarik untuk mengikuti kegiatan virtual tour dan bersedia membayar mulai dari rentang harga $\mathrm{Rp}$. 10.000-Rp.50.000 dalam satu kegiatan virtual tour jika diadakan di kemudian hari.

\section{Saran}

Dari hasil temuan di atas melihat adanya minat generasi millenial untuk membeli layanan virtual tour maka diperlukan pengembangan kedepan untuk menjadi sebuah peluang bisnis yang baru dan perlu adanya penelitian lebih lanjut terkait dengan hal itu. 


\section{Kepustakaan}

Akdon dan Riduwan. (2013). Rumus dan Data dalam Analisis Staitistika. Bandung: Alfabeta.

Anwar, T.A, Puspita Y.(2020). Public Intention on Banding Tour on Bus. JOINT (Journal of Information Technology), 2(1), 13-16.

Cho,Y.H, Wang,Y. Fesenmaie,D.R. (2002) Searching foe Experiences: The webbased Virtual Tour in Tourism Marketing. Journal of Travel and Turism Marketing, 12(4), 1-17.

El-Said, Osman and Aziz, Heba (2021). Virtual Tours a Meand to an End: An Analysis of Virtual Tours Role in Tourism ecovery Post COVID-19. Journal Of Travel Research I(21): 1- 16.

Hana, Kharis Fadlullah. (2019). Minat Beli Online Generasi Milenial: Pengaruh Kepercayaan dan Kualitas Layanan. Jurnal Bisnis dan Manajemen Islam. 7(2). 203.

Hidayatullah, S., Rachmawati, IK, Arosanto.E., Waris. Abdul, Patalo RG. (2020). Sistem Informasi Pelayanan dan Entrepenual Marketing serta kepuasan Generasi Millenilal Berkunjung ke Tempat Wisata. Jurnal Ilmiah Bisnis dan Ekonomi Asia. 14 (1). 74-83.

Huang YC., Backman S.J., Backman K.F. (2010) The Impacts of Virtual Experiences on People's Travel Intentions. In: Gretzel U., Law R., Fuchs $M$. (eds) Information and Communication Technologies in Tourism 2010. Springer, Vienna. https://doi.org/10.1007/978-3-21199407-8_46.

Namrata Bakre,A.D.(2017). Campus Virtual Tour. International Journal Of Advenced Research Computer Engineering and Technology. 444-448.

Prasetya, D.D.(2011). Aplikasi Virtual Tour Berbasis Web Sebagai Media Promosi Pariwisata. Seminar On Elctrical, Informatics, And Its Education, (hal.5863).

Pladitama, R.(2015). Virtual Tour Pada Situs Trowulan Mojokerto Menggunakan $\begin{array}{lll}\text { Panorama } & 360 & \text { (Doctoral }\end{array}$
Disseration).Insitut Teknologi 10 November.

Sarwono, J. (2009). Statistik itu Mudah: Panduan Lengkap untuk Belajar Komputasi Statistik, SPSS 16. Yogyakarta: Andi Offset.

Sousa, R, Voss.C.A.(2009). The Effect of Service Failures and Recovery onn Costumer Loyalty in E-ServicesL An Empirical Investigation. International Journal Of Operation and Production Management.. 29(8), 834-864. https://doi.org/10.1108/0144357091097 7715.

Tjiptono, F. Chandra G. (2005). Manajemen Kualitas Jasa. Yogyakarta: Andi.

Wulur, H.W. Sentinuwo, S. Sugiarso, B. (2015). Aplikasi Virtual Tour Tempat Wisata Alam di Sulawesi Utara. Jurnal Teknik Informatika. 6(1) 
Jurnal IPTA (Industri Perjalanan Wisata)

Vol. 9 No. 2, Desember 2021

p-ISSN: $2338-8633$

e-ISSN: 2548-7930 